\title{
Effectiveness of Loving Pregnancy Massage To Quality Sleep, Pain and Anxiety on Mother Pregnant Trimester III
}

\author{
Etin Rohmatin) Sariestya Rismawati ${ }^{2)}$ \\ Email : erin_yusar@yahoo.com
}

\begin{abstract}
Background: During the period of pregnancy the mother suffered various complaints which cause discomfort due to changes in the physical as well as changes in psychological. As for the changes in the physical that is often experienced when pregnant include pain back, cramping legs, shortness of breath , frequent urination and responses psychic who experienced mother Pregnant form of depression , stress, anxiety and disturbance to sleep such as insomnia or difficulty in start sleeping

Methods: The study is a pre- experiment with the design of the study is One group pretest-posttest design with the use of questionnaires in in Region Work Puskesmas Purbaratu on month in January and February 2019. Taking the sample in the study is using purposive sampling which totaled 31 people. Analysis of the data is done by univariate and bivariate by using Kruskal Wallis test.

Results: The sleep quality of pregnant women before doing massage was in the category of moderate sleep disorders as many as 20 people $(64.5 \%)$ while after massage in the category of good sleep quality , there were 17 people (54.8\%). The pain of a mother pregnant before do massage on the category of light that as many as 21 people (67.7\%). After doing massage in the light category, there were 19 people $(61.3 \%)$. Anxiety in the mother pregnant before do massage on the category of light that as many as 21 people $(71.0 \%)$. When do massage all respondents in a category does not exist anxiety that as many as 31 people $(100 \%)$. Signfikansi more substantial than $0.05(0.172>0.05)$ means that not there is a difference significant effectiveness loving pregnancy massage to the quality of sleep, pain and anxiety mother pregnant third trimester in Region Work Puskesmas Purbaratu City of Tasikmalaya in 2019.

Conclusion: The results of testing the value of Chi Square table df $=25991>$ Chi-square count 3523 and the value Asymp.Sig ( asymtopic significance) sebesae 0.172, because signfikansi more substantial than $0.05(0.172>0.05)$ then the hypothesis Ho accepted means no There is a significant difference in the effectiveness of loving pregnancy massage on the quality of sleep, pain and anxiety of third trimester pregnant women in the Tasikmalaya City Purbaratu Health Center Work Area in 2019.
\end{abstract}

Keyword : quality sleep; pain; anxiety; pregnancy loving Massase

1, 2, 3) Poltekkes Kemenkes Tasikmalaya, Indonesia

Jalan Cilolohan No. 35 Kota Tasikmalaya Jawa Barat 46115, Indonesia

Background. During the period of pregnancy the mother suffered various complaints which cause discomfort due to changes in the physical as well as changes in psychological. As for the changes in the physical that is often experienced when pregnant include pain back, cramping legs, shortness of breath, frequent urination and responses psychic who experienced mother pregnant in the form of depression, stress, anxiety and disturbance to sleep such as insomnia or difficulty in start sleeping (Ministry of RI, 2014).

In the third trimester, stress and anxiety in pregnant women will increase, this happens because the condition of the pregnancy is getting bigger and the psychological condition of the third trimester is more complex. The condition is not infrequently lead to problems such as positioning beds were less comfortable and easily attacked tired and getting him the time of delivery will make the level of stress the mother is getting higher. Feelings of anxiety appears to dikarekan mother think of the process of childbirth , the pain of labor and the condition of the baby that will be born later ( Janiwarty \& Pieter, 2013).

Impaired sleep, pain and anxiety that is experienced by the mother pregnant can be resolved by various means such as by engineering the pharmacological and nonpharmacological. Methods of pharmacology 
given to patients who experience disorders sleep is to give the drug class of sedativehypnotics such as benzo diazepin , triazolam, temazepam and lorazepam. Therapy Pharmacologic give effect that fast but if given within a time period long may cause effects danger to the health of the mother pregnant because can give risk of disruption of growth and development of the fetus . (Ronald HS, 2011).

One of the methods of non-pharmacological which is recommended for mothers pregnant in overcoming disorders sleep, pain and anxiety during pregnancy is pregnancy massage, acupuncture, relaxation, yoga, therapy chiropactic (Field et al, 2010). Or use sleep management during pregnancy by adjusting sleeping positions, taking warm baths, drinking warm milk, listening to music, exercising and doing massage (Ronald HS, 2011).

Various kinds of massage techniques for pregnant women, one of which is loving pregnancy massage. Loving Pregnancy massage is one of the therapeutic holistic which begins with relaxation breathing then prayed to God begging welfare body, mind and spirit, continued to bring a sense of caring , loving and full of love masseuse at the mother with sincere (Widyawati et al , 2018)

The results of the study research the Touch Research Institute at the Medical University showed pregnancy massage has the effect that is positive in the mother pregnant, especially in reducing stress and depression, reduce pain on the part of the back and legs, preventing the birth of a baby prematurely and reduce symptoms of depression after childbirth ( Urtnowska , 2017).

Based on the data obtained from the Department of Health City of Tasikmalaya number of visits Mother pregnant reaches 9331 people with incidence mother pregnant with hypertension, a number of 293 people and the incidence of weight infants born low in 2017 as much as $2.9 \%$ birth of life ( DHO Kota Tasikmalaya , 2018).
Data were obtained from the Health Center Purbaratu the month of January to October to visit Mother pregnant reaches 666 people and for mothers pregnant third trimester ie 272 mothers pregnant. Genesis labor with action SC region puskesmas Purbaratu month of January - November as many as 78 cases , was born prematurely 18 cases, LBW 7 cases, and pregnancies with hypertension as many as 59 cases. The results of interviews of midwives , mothers pregnant third trimester who do counseling on average say hard to sleep since entering the third trimester, usually occurs when awakened at night the day and not able to start sleeping back. In addition it also turns the pain is felt like a sore back, sore legs, sore waist.

Based on the description of the background behind the above, the researcher doing research is to know the difference in the effectiveness of loving pregnancy massage to the quality of sleep, pain and anxiety in mothers pregnant third trimester in the region work Puskesmas Purbaratu City of Tasikmalaya Year 2019.

Methods. This research is a preexperiment. The research design is One Group Pretest-Posttest Design using a questionnaire. The population in this study were pregnant women in the Purbaratu Puskesmas Tasikmalaya City Work Area in January February 2019 as many as 31 pregnant women. The sample in this study were third trimester pregnant women who met the inclusion and exclusion criteria. Inclusion criteria, namely pregnant women in the third trimester, pregnant women who live permanently in the working area of Purbaratu Health Center, are willing to be respondents in this study. The exclusion criteria were pregnant women with certain health problems and diseases such as physical ailments, environmental problems, psychological stress, excessive fatigue, medical indications, and poor nutrition. and pregnant women who consume certain drugs. The research sample was obtained using a purposive sampling method. The independent variable in this study 
is loving pregnancy massage. Dependent variables (dependent variables) in this study were sleep quality, pain, and anxiety. The instrument used to measure sleep quality is the Pittsburgh Sleep Quality Index (PSQI) which has been developed by Contreras et al., (2014). The sleep quality questionnaire consists of open and closed questions.

Interpretation of the sleep quality score is very good if the score is $1-5$, mild sleep disturbances are 6-7, moderate sleep disturbances are 8-14 and sleep disorders are poor if the scores reach 15-21. The research instrument used in measuring anxiety is the Hamilton Rating Scale For Anxiety (HARS) scale measuring tool. The HARS scale is a measure of anxiety based on the appearance of symptoms in individuals who are experiencing anxiety. Each item that is observed is given 5 levels of score (Likert score) between 0 (zero percent) to 4 (severe). The NRS sheet is used as a measuring tool for pain intensity or level of pain with a value range of 0 (zero) no pain, 1-3 (mild pain), 4-6 (moderate pain), 7-10 (severe pain).

Result and Discussion. The results and discussion contain scientific research/ development findings and discussions. Scientific findings (scientific finding) obtained from the results of research that has been carried out are described in this chapter but must be supported by adequate data. The scientific findings referred to here are not data obtained from research results (can be attached as supplementary files). The scientific findings must be explained scientifically including: What scientific findings were obtained? Why did that happen? Why are trend variables like that? All these questions must be explained scientifically, not only descriptive, if necessary supported by adequate scientific basis phenomena. In addition, it must be explained the connection with the existing concepts and their comparison with previous studies, whether the results of the study are appropriate or not, better or not and other aspects. Result describe the major findings of the study. It should be clear, concise and can be reports on texts or graphics. Please provide some introduction for the information presented on tables or images.
The discussion should be explore the significance of the results of the study. The following components should be covered in discussion. How do your result relate to the original question or objectives outlined in the background section (what)? Do you provide interpretation scientifically for each of your results or findings presented (why)? Are you result consistent with what other investigators have reported (what else)? Or are there any differences?

\section{Conclusion and Suggestions.}

Table 1. Distribution Frequency Quality Sleeping Mom Pregnant Trimester III Prior to Do Loving Pregnancy Massage

\begin{tabular}{lcc}
\hline \multicolumn{1}{c}{ Category } & F & $\%$ \\
\hline Sleep quality is good & 0 & 0 \\
Mild sleep disturbance & 10 & 32.3 \\
Moderate sleep disturbance & 20 & 64.5 \\
Bad sleep disturbance & 1 & 3,2 \\
\multicolumn{1}{c}{ Amount } & 31 & 100 \\
\hline
\end{tabular}

Based on Table 4.1 in mind that the quality of sleep mother pregnant third trimester in Region Work Puskesmas Purbaratu City of Tasikmalaya in 2019 before do massage most substantial in the category of disorders sleep was that as many as 20 people $(64.5 \%)$, while most of the small to the category of disorders sleep badly that much 1 person (3.2\%)

Table 2. Distribution Frequency Quality Sleeping Mom Pregnant Trimester III When Do Loving Pregnancy Massage

\begin{tabular}{lcc}
\hline \multicolumn{1}{c}{ Category } & F & $\%$ \\
\hline Sleep quality is good & 17 & 54.8 \\
Mild sleep disturbance & 7 & 22.6 \\
Moderate sleep disturbance & 7 & 22.6 \\
Bad sleep disturbance & 0 & 0 \\
Amount & 31 & 100 \\
\hline
\end{tabular}

Table 2. showed that the quality of sleep in mother pregnant third trimester after do loving pregnancy massage in the category of quality sleep well that as many as 17 people (54.8\%).

Based on the results of the study, it was shown that the sleep quality of pregnant women before the massage was mostly in the moderate sleep disorder category, namely as many as 20 people $(64.5 \%)$ while a small proportion was in the bad sleep disorder category, namely 1 person (3.2\%). This is because the quality of sleep for pregnant women is still lacking and many factors affect the quality of sleep for pregnant women 
including physical, environmental, psychological and drug use factors. As a result of this disturbance, it affects the length of time it takes for the mother to sleep at night, the mother feels sleepy when she wakes up in the morning, feels uncomfortable and does not feel refreshed when she wakes up in the morning, and the mother feels tired when doing activities in the morning.

Based on the results of the study were conducted from several studies similar, the researchers found that most great mother pregnant third trimester experienced disruption to sleep , things like dikemukan by Wahyu (2012) that $80 \%$ of mothers experienced disruption to sleep during the period of pregnancy are caused by due to changes in physiological so mom pregnant difficulties to obtain a position that is comfortable when sleeping . In the study, researchers discovered several respondents said that the more the growing uterus mother pregnant sometimes difficult to determine the position of the bed, hot and often woke up in the night the day .

Benefits of Loving Pregnancy massage can reduce anxiety in mothers pregnant which caused changes in hormonal during pregnancy and reduce the discomfort of muscle such as cramps, tension muscle, pain back part of the bottom and stiffness of the neck and can relax the muscles and tone that occur increase fleksibility muscles were very helpful during late pregnancy and childbirth. Massage also can help soothe and relax the mother pregnant so that mothers can feel the beds are more qualified ( Widyawati et al, 2018).

Table 3. Distribution Frequency Pain On Mother Pregnant Trimester III Prior to Do Loving Pregnancy Massage

\begin{tabular}{lcc}
\multicolumn{1}{c}{ Category } & F & $\%$ \\
\hline No Pain & 1 & 3,2 \\
Mild Pain & 21 & 67.7 \\
Moderate Pain & 8 & 25.8 \\
Severe pain & 1 & 3,2 \\
$\quad$ Amount & 31 & 100 \\
\hline
\end{tabular}

Based on Table 3 in mind that the pain of a mother pregnant third trimester in Region Work Puskesmas Purbaratu City of Tasikmalaya in 2019 before do massage most substantial in the category of light that as many as 21 people $(67.7 \%)$, while most of the small to the category of pain severe and no pain is as much 1 person (3.2\%).
Table 4. Distribution Frequency Pain On Mother Pregnant Trimester III When Do Loving Pregnancy Massage

\begin{tabular}{lcc}
\hline \multicolumn{1}{c}{ Category } & F & $\%$ \\
\hline No Pain & 19 & 61.3 \\
Mild Pain & 12 & 38.7 \\
Moderate Pain & 0 & 0 \\
Severe pain & 0 & 0 \\
$\quad$ Amouth & 31 & 100 \\
\hline
\end{tabular}

Based on table 4. in mind that the pain of a mother pregnant third trimester in Region Work Puskesmas Purbaratu City of Tasikmalaya in 2019 after done massage most substantial in the category of light that as many as 19 people $(61.3 \%)$, while most of the small to the category of light that as many as 12 people $(38,7 \%)$

Pain in pregnant women in the third trimester in the Work Area of the Purbaratu Puskesmas, Tasikmalaya City in 2019 before the massage was carried out, was mostly in the mild category, namely 21 people $(67.7 \%)$ while a small proportion was in the category of severe pain and no pain, namely 1 person (3, $2 \%)$.

A sense of pain that is felt by the mother hami is a thing that is complex, includes the effect of physiological, social , spiritual, psychological and cultural . Psychological factors can also affect the level of pain . Factors that consists of anxiety and technique of coping. Anxiety can increase the perception of pain . Coping techniques affect the ability to cope with pain . Factors culture consists of the meaning of pain and tribal peoples. Meaning the pain is something that means a person as the pain will affect the experience of pain and how a person adapts to the conditions mentioned.

The pain of a mother pregnant third trimester in Region Work Puskesmas Purbaratu City of Tasikmalaya in 2019 after done massage all respondents in a category does not exist anxiety that as many as 31 people (100\%).

Massage the mother pregnant is one of the ways that can reduce stress and improve the welfare of the mother and fetus. Reduce the discomfort of muscle, such as cramps, tension muscle during pregnant, such as pain back part of the bottom, stiffness of the neck , cramps leg, dizziness head, edema and ankle foot swelling Massage can help reduce depression and anxiety in mothers pregnant 
which caused changes in hormonal during pregnancy

Table 5. Distribution Frequency Anxiety On Mother Pregnant Trimester III Prior to Do Loving Pregnancy Massage

\begin{tabular}{lcc}
\hline \multicolumn{1}{c}{ Categor } & F & $\%$ \\
\hline Not there is anxiety & 3 & 9.7 \\
Mild anxiety & 22 & 71.0 \\
Moderate Anxiety & 6 & 19.4 \\
Severe Anxiety & 0 & 30 \\
Amount & 31 & 100 \\
\hline
\end{tabular}

Based on Table 5 was known that anxiety in mothers pregnant third trimester in Region Work Puskesmas Purbaratu City of Tasikmalaya in 2019 before do massage most substantial in the category of light that as many as 21 people $(71.0 \%)$, while most of the small to the category does not exist anxiety that as many as 3 people $(3.7 \%)$.

Table 6.Distribution Frequency Anxiety On Mother Pregnant Trimester III When Do Loving Pregnancy Massage

\begin{tabular}{rcc}
\hline Category & F & $\%$ \\
\hline Not there is anxiety & 31 & 100 \\
Mild anxiety & 0 & 0 \\
Moderate Anxiety & 0 & 0 \\
Severe Anxiety & 0 & 0 \\
Amouth & 31 & 100 \\
\hline
\end{tabular}

Based on Table 6 was known that anxiety in mothers pregnant third trimester in Region Work Puskesmas Purbaratu City of Tasikmalaya in 2019 after done massage all respondents in a category does not exist anxiety that as many as 31 people (100\%)

Based on the results of the research that has been done on the level of anxiety in the mother pregnant before do massage most substantial in the category of light that as many as 21 people $(71.0 \%)$, while most of the small to the category does not exist anxiety that as many as 3 people (3.7\%). Factors most much influence anxiety mother pregnant third trimester in research this is caused due to lack nyamanan that is felt by the mother .

Factors that may affect anxiety appear on mothers pregnant third trimester are caused due to lack nyamanan perceived, their tramu labor before, and the readiness of the mother of iron and when labor is getting close. In general there are two factors that influence anxiety in mothers pregnant, are factors internal and factors external . Internal factors are divided into two types, namely beliefs about childbirth and feelings before childbirth . While external factors are also divided into two, namely information from health workers and support from husbands ( Shodiqoh , 2014 in Rahmitha , 2017). Factors biological and factors psychic that influence anxiety in mothers pregnant. Biological factors include health and strength during pregnancy and fluency in delivering the baby. While the factors psychic as readiness mentally mother pregnant during pregnancy until birth where there is feeling anxious, tense, unhappy and various kinds of feelings of others as well as problems such as miscarriage, appearance and ability to give birth (Maimunah , 2009).

Based on the results of the research that has been done on the level of anxiety in the mother pregnant third trimester in Region Work Puskesmas Purbaratu City of Tasikmalaya in 2019 after done massage all respondents in a category does not exist anxiety that as many as 31 people (100\%).

Table 7. Results Kruskal Wallis Difference Effectiveness Effect of Loving Pregnancy Massage To Quality Sleep , Pain and Anxiety

\begin{tabular}{lccccc}
\hline Category & N & $\begin{array}{c}\text { Mean } \\
\text { Rank }\end{array}$ & $\begin{array}{c}\text { Chi- } \\
\text { Square } \\
\text { hitung }\end{array}$ & $\begin{array}{c}\text { Chi- } \\
\text { Squar } \\
\text { e tabel }\end{array}$ & $\begin{array}{c}\text { Asym } \\
\text { p. Sig }\end{array}$ \\
\hline Sleep Quality & 31 & 47,35 & & Df 2 & 0,1 \\
Pain & 31 & 40,48 & 3,523 & $(5,99$ & 72 \\
Worry & 31 & 53,16 & & $1)$ & \\
\hline
\end{tabular}

Based on Table 7 has been tested by using the Kruskal Wallis value of Chi Square table df $=2$, namely 5.991 and Chi square arithmetic 3.523, because the price of Chi Square table DF2 5 , 991> Chi Square count 3 , 523, then hipotess and value Asymp.Sig ( asymtopic significance) sebesa $r$ 0.172, because signfikansi more substantial than $0.05(0.172>$ $0.05)$ then the hypothesis Ho accepted means not there is a difference significant effectiveness loving pregnancy massage to the quality of sleep, pain and anxiety mother pregnant third trimester in Region Work Puskesmas Purbaratu, Tasikmalaya City in 2019.

Based on the test results using the Kruskal wallis test, the Chi Square table value is $\mathrm{Df}=2$ 5.991> Chi square count 3.523, then the hypotess and Asymp.Sig value (asymtopic 
significance) is 0.172 , because the significance is greater than $0.05(0.172>0.05)$ then the Ho hypothesis is accepted, meaning that there is no significant difference in the effectiveness of loving pregnancy massage on the quality of sleep, pain and anxiety of third trimester pregnant women in the Purbaratu Public Health Center, Tasikmalaya City in 2019.

Their influence of loving pregnancy massage to the quality of sleep, pain and anxiety in mothers pregnant third trimester are caused due to massage mom pregnant sense of tranquility, no stress and no camas during pregnancy, thus giving the impact on quality of sleep mother pregnant. In the physiological effects of relaxation on a massage involving the nerve of the parasympathetic in the system nerve center. One of the functions of nerve of the parasympathetic this is to bring down the production of hormones adrenaline or epinephrine (a hormone of stress) and increases the hormone noradrenaline or norefinefrin (hormone relaxes) that occurs decrease anxiety and tension on the mother pregnant which resulted in the mother pregnant becomes more relaxed and quiet ( Wulandari 2006 ). In research conducted by Atika year 2013 giving massage in a time long can give the effect of relaxation that is more profound, memaksimalkankan process of stretching the muscles and increases the elasticity of tissue.

Loving Pregnancy massage is a massage that is done on mothers pregnant to facilitate the circulation of the blood of mothers and reduce the complaints that are often experienced by the mother was pregnant. The type of massage is adjusted to the changes in the body of pregnant women. Loving pregnancy massage the mother pregnant may help to put out the products of metabolism of the body through the lymphatic and system of circulation, which can reduce fatigue and make the mother more energy, the system of circulation which is smooth to ease the burden of work the heart and help pressure the blood of the mother pregnant becomes normal, discomfort muscles such as cramps, tension muscles, stiffness of muscles that are often perceived by the mother was pregnant, can be reduced with a massage. Loving pregnancy massage also can help reduce depression and anxiety in mothers pregnant which caused changes in hormonal during pregnancy, soothe and relax the mother pregnant are experiencing anxiety, so that mothers pregnant can feel the beds are quality ( IHCA , 2014).

Quality sleep poorly are experienced mothers pregnant during the study is due for waking up the middle of the night, hard to sleep or insomnia, overheating or chills, sore backs down, difficult to determine the position of sleep and often sleepy at noon today. The cause of the quality of sleep that bad can be caused by a sore back. Mothers pregnant tend to be lordosis will stretch the muscles back and give rise to a sense of pain or pain due to withstand the load weight which is brought into the uterus . Insomnia and waking up in the night today are caused because of discomfort due to uterus enlarges, the movement of the fetus in the evening the day and because of worries and anxiety about her pregnancy that caused the mother to experience difficulty sleeping. (Romauli , 2011).

Relaxation is a complementary therapy that can be used to treat anxiety by creating an atmosphere of relaxation. Therapy that is yoga, meditation, acupuncture , massage, therapy music, respiratory diaphragm, the activities of which are based by speritual, hypnosis, aroma therapy . Pregnant massage itself has a positive effect on pregnant women by reducing levels of the hormone cortisol to reduce stress, neropineprin to reduce anxiety, and serotonin to reduce pain in the back and legs (Field et al, 2010).

Acknowledgements. Thanks to the researchers say to all those who have helped in completing this research

\section{References}

Asrinah. Putri, SS. Sulistyorini, D. Muflihah AS. Sari, DN. 2010. Asuhan Kebidanan Masa Kehamilan. Yogyakarta: Graha IImu.

Alza, N. dan Ismarwati. 2017 Faktor-faktor yang Mempengaruhi Kecemasan lbu Hamil Trimester III, tersedia dalam: https://ejournal.unisayogya.ac.id diakses pada tanggal 11 November 2018

Dahlan, MS. 2010. Besar sampel dan cara pengambilan sampel dalam penelitian kedokteran dan kesehatan. Edisi 3. Jakarta: Salemba Medika

Dahlan, MS. 2016. Pintu Gerbang Memahami Statistik, Metodologi dan Epidemiologi (Edisi 2). Jakarta : Epdemiologi Indonesia 
Field et al. 2010. Prenatal Depression Effects and Intervention: a review. Infant Behavior and Development, 33(4), 409-418.

Hidayat AA. 2008. Pengantar Konsep Dasar Keperawatan. Jakarta: Salemba Medika.

Janiwarty, B dan Pieter, Z. 2013. Pendidikan Psikologi untuk Bidan: Suatu Teori dan Terapannya Edisi 1. Yogyakarta: Rapha Publishing.

Kemenkes RI. 2014. Pegangan Fasilitator Kelas Ibu Hamil. Jakarta: Kementerian Republik Indonesia. Humanty, Hal 61-67

Marpaung Lenny M. 2011 Gambaran Kecemasan dan Nyeri Persalinan Pada Ibu Primigravida di KlinikBersalin Sally Medan 201,tersedia dalam https://repository.usu.ac.id/handle/123456 $789 / 27191$ diakses pada tanggal 20 November 2018

Maimunah. 2009 Kecemasan Ibu Hamil Menjelang Persalinan Pertama, Jurnal

Novitasari, B. dan Mabruri, M. 2013 Keefektivan konseling kelompok PraPersalinan Untuk Menurunkan Tingkat Kecemasan Primigravida

Notoatmodjo, S. 2012. Metode Penelitian Kesehatan. Jakarta: Rineka Cipta.

Prananingrum, R. Hidayah, N. 2018. Efektifitas Loving Massage In Pregnancy Terhadap Pola Tidur Pada Ibu Hamil Primigravida di Wilayah UPTD Puskesmas Pajang Kota Surakarta, tersedia dalam http://www.jurnal.stikes- aisyiyah.ac.id/index.php/gaster/article/vie w/296 diakses tanggal 8 Desember 2018.

Prawirohardjo, S. 2013. IImu Kebidanan. Jakarta: PT Bina Pustaka.

Ronald, HS. 2011. Pedoman dan Perawatan Kehamilan Yang Sehat dan Menyenangkan. Bandung: CV Nuansa Aulia.

Sanningtyas. (2013). Studi Kualitas tidur Pegawai Institute Pertanian Bogor, tersedia dalam: http://repository.ipb.ac.id/jspui/bitsream/1 23456789/61465/1/ diakses tanggal 5 Desember 2018.

Shodiqoh, ER. dan Syahrul, F. 2014. Perbedaan Tingkat Kecemasan Dalam Menghadapi Persalinan antara Primigravida dan Multigravida, Jurnal Berkala Epidemiologi, Hal:141-150

Sugiyoni. 2010. Metode Penelitian Pendidikan (Pendekatan Kuantitatif Kualitatif dan $R \& D)$. Bandung: Alfabeta.

Sulisdiana. 2017. Pengaruh Pijat Bumil terhadap Kualitas Tidur pada Ibu hamil Trimester III di BPM Bidan A Desa Karang Nongko Kabupaten Mojokerto, Tersedia dalam http://ejournalp2m.stikesmajapahitmojoke rto.ac.id/index.php/ diakes tanggal 1 Desember 2018.

Widyawati, M.N. Suprihatin, K. Sutarmi. 2018. Loving Pregnancy Massage. Semarang: IHCA 